\title{
Care and management demands of long-term care facilities for the elderly in Brazil: an integrative review (2004-2014)
}

Fátima Ferreira Roquete ${ }^{1}$ Carolina Campos Ricci Frá Batista² Rodrigo Caetano Arantes $^{3}$

\section{Abstract}

Objective: to analyze the care and management demands of Long-Term Care Facilities for the Elderly (LTCFs) in Brazil. Method: an integrative review of literature was carried out, organized into six stages: a) elaboration of a guiding question; b) online search of LILACS, SciELO, PubMed, the CAPES Portal and the Brazilian Society of Geriatrics and Gerontology databases; c) article selection, following the exclusion and inclusion criteria, with the sample composed of 17 articles; d) commented analysis of the selected articles; e) deliberation on the results obtained, formulated from the synthesis and interpretation of the selected studies; f) presentation of the results of the review. Results: the care demands identified are related to the process of caring and assume a working team with geriatric and gerontological knowledge, while the management demands include the means and resources needed so the care can be provided effectively. However, the LTCFs were found to rely on professionals who are unprepared to provide care or to assume an organizational management role, meaning care for the elderly is restricted to the essentials for their basic needs. Conclusion: the care demands were easily identified in the analyzed publications, however, there is a lack of research that evaluates management demands in a broader and more in-depth manner. It is suggested that studies aiming to broaden theoretical knowledge of the care and management demands of LTCFs are carried out, to stimulate effective and positive actions in the practices of these institutions, seeking to offer top quality care to elderly persons that live in these facilities, that responds to the real needs of their current stage of life.

\footnotetext{
Universidade Federal de Minas Gerais, Departamento de Enfermagem Aplicada, Curso de Gestão de Serviços de Saúde, Núcleo de Gestão em Saúde (NUGES). Belo Horizonte, MG, Brasil.

2 Universidade Federal de Minas Gerais Departamento de Enfermagem Aplicada, Curso de Gestão de Serviços de Saúde. Belo Horizonte, MG, Brasil.

3 Conselho Estadual do Idoso de Minas Gerais, Comissão de Políticas Públicas. Belo Horizonte, MG, Brasil.
}

Keywords: Homes for the Aged. Health Management. Institutionalized Elderly. 


\section{INTRODUCTION}

The growth of the elderly population has resulted in uncertainty in relation to the care provided to elderly persons, as aging takes place in a context of socioeconomic and cultural changes to the value systems and family arrangements of elderly persons ${ }^{1}$. In addition, longevity is not synonymous with healthy aging, as it may be accompanied by an increase in chronic-degenerative diseases and functional and/ or cognitive disabilities, requiring a third party to take responsibility for the required care ${ }^{2}$.

Such care was traditionally largely attributed to women, but due to a greater insertion in the labor market they now encounter difficulties in reconciling their roles, which include providing care for the elderly. The meeting of such needs in the family context has therefore been hampered, either by the unavailability of a family member, or by family conflicts and/or the absence of a caregiver in the home of the elderly persons ${ }^{2,3}$. As a result of these developments, which are a major concern for society, residence in Long Term Care Facilities for the Elderly (LTCFs) has emerged as an alternative to be considered.

Even though Brazilian laws guarantee the rights of elderly persons in their family and the community, many depend on the care offered by LTCFs, defined, according to the resolutions of the Agência Nacional de Vigilância Sanitária (the National Agency of Sanitary Surveillance) (ANVISA) ${ }^{4}$, as "governmental or non-governmental institutions of a residential nature, intended to provide the collective domicile of persons aged 60 or over, with or without family support, in conditions of freedom, dignity and citizenship". As they are institutions for the elderly population, it is essential to understand their possible care and management demands.

Demand, in the context of care, is understood as the "quantum of a given product or service that is collectivity required or sought, or which, by means of forecasts, it is estimated that will be required and sought by a certain date" ${ }^{5}$. Care consists of the "assiduity in the accompaniment of an individual and providing them with care"; as well as "a set of activities of care to those in need, carried out by specialized organizations or institutes" 5 .
In addition to care demands, LTCFs have management needs which are specific to the services offered by these institutions, as well as potential particularities in the management of this type of organization. Management is taken here to mean the "action of managing, directing or administering"5 an institution.

In this context, there is a tendency for the need for LTCFs to increase in the near future, meaning greater knowledge of the reality of these institutions, and how they organize themselves to meet the requirements of elderly persons, is vital. Thus, the question that guided the present study was: "What are the care and management demands of LTCFs?". The objective of the research was therefore to analyze the care and management demands of LTCFs, in the period 2004-2014.

\section{METHOD}

In view of the proposed objective, which was to analyze the care and management demands of LTCFs in the period 2004-2014, an integrative literature review was carried out. This method consists of the synthesis of the knowledge and the incorporation of the applicability of results of significant studies in this area ${ }^{6}$. Thus, the present review was divided into six stages, as recommended by literature ${ }^{6}$.

In the first stage, the guiding question of the study, presented in the Introduction, was elaborated. The second stage consisted of a search of publications. Before beginning, a consultation was made of the Descriptors in Health Sciences (DeCS), provided by the Virtual Health Library (VHL) portal, and "LTCF", "Administration of Human Resources in Health", "Quality Management", "Health Management", "Management Indicators", "Clinical Governance" and "Health Manager" were adopted as search items.

The searches of the databases were carried out in the first six months of 2015. The following online sources were used: Literatura Latino-Americana e do Caribe em Ciências de Saúde (Latin American and Caribbean Health Sciences Literature) (LILACS), Scientific Electronic Library Online (SciELO), Biblioteca Virtual em Saúde (the Virtual Health Library) (BVS-BIREME), the US National Library 
of Medicine and National Institutes of Health (PubMed/NCBI) and the Publications Portal of the Centro de Aperfeiçoamento do Pessoal de Nível Superior (the Center for the Improvement of Higher Education Personnel) (CAPES). The portal of the Sociedade Brasileira de Geriatria e Gerontologia (the Brazilian Geriatrics and Gerontology Society) (SBGG) was also consulted.

In the third stage, the publications of interest for the study were selected. The following inclusion criteria were applied: articles with abstracts and complete texts available in the data sources consulted, in Portuguese, English and Spanish, published between 2004 and 2014. The definition of the period was based on the dates of the main legislation related to the care of the elderly and the functioning of LTCFs in Brazil, especially the International Plan of Action on Aging of the United Nations (UN) and Collegiate Board of Directors Resolution (RDC) n. 283 of $\mathrm{ANVISA}^{4}$, in 2005.

At first, only the descriptor "Long Term Care Facility for the Elderly" was used, allowing an overview of all the types of study involving LTCFs in Brazil. In this stage, the SciELO database was included, in which 60 articles were identified, while the BVS search identified 11,885 publications, giving a total of 11,945 studies. After applying the inclusion criteria, 110 publications were obtained.

Subsequently, this descriptor was crossed with the others, using the "and" descriptor or the "or" descriptor, thus refining the scope of this review. Data were classified by data sources: 60 publications in SciELO, 110 in Lilacs, four in BVS, six in PubMed, 37 in the Capes Portal and seven in the SBGG Portal, with 224 publications selected in this stage.

The fourth step was devoted to the critical analysis of the 224 studies. This was carried out rigorously and, to continue the selection of the publications, a careful reading was performed in search of evidence related to the guiding question of the research, considering title and summary. Theses, dissertations and monographs were excluded in order to ensure the uniformity of studies. In order to identify the properties of the articles that composed the review, the TREND Statement evaluation instrument was applied. This is a checklist composed of 59 criteria distributed in five sections: title and abstract; introduction; methodology; results; discussion, and the expertise of the authors in the subject. It was verified that $70.4 \%$ of the articles considered topics related to the title and abstract section; $88.25 \%$, the largest percentage, dealt with the topics of the introduction section; $58.8 \%$ covered the topics of the methodology section of the checklist; $53.6 \%$ met the criteria related to results; while $80.4 \%$ of the articles met the requirements of the discussion section of the evaluation instrument.

A total of 56 articles were identified in this phase. However, it was found that some were duplicates, and these were removed. With a new, careful re-reading of the abstracts and a reading of the introductions of the articles, the 17 articles that composed the present review were selected.

The fifth stage was devoted to the discussion of the results, elaborated from the synthesis and interpretation of the 17 selected studies. The central ideas of the authors and their studies were demarcated and/or underlined, aiming at a better understanding and elaboration of the synoptic framework. This enabled the organization and presentation of the data, including: title of the article, authors, periodical/ year of publication, objective/participants/sample of the study, and the type of care and/or managerial demands identified.

The sixth stage included the clear and complete presentation of the review, which was carried out, as recommended by the literature, in order to reach the objectives proposed by the authors and the critical evaluation of the results by the reader ${ }^{6}$.

\section{RESULTS}

The articles were inserted in the synoptic table, presented below, according to the year of publication, from the most recent to the oldest. 
Table 1. Synoptic table of articles that comprised the integrative review, 2015

\begin{tabular}{|c|c|c|c|}
\hline Articles and Authors & $\begin{array}{l}\text { Publication and } \\
\text { Year }\end{array}$ & $\begin{array}{l}\text { Objective and Participants/Study } \\
\text { Sample }\end{array}$ & $\begin{array}{l}\text { Care and/or management } \\
\text { demands identified and type } \\
\text { of LTCF. }\end{array}$ \\
\hline $\begin{array}{l}\text { Degree of dependence } \\
\text { of elderly persons } \\
\text { resident in Long Term } \\
\text { Care Facilities. } \\
\text { Marinho et al. }\end{array}$ & $\begin{array}{l}\text { Revista Gaúcha } \\
\text { de Enfermagem } \\
\text { (Gaúcha Nursing } \\
\text { Journal) } \\
2013\end{array}$ & $\begin{array}{l}\text { Identify the degree of dependence of } \\
\text { institutionalized elderly persons. } \\
125 \text { elderly persons resident in three } \\
\text { LTCFs / Montes Claros, Minas } \\
\text { Gerais. }\end{array}$ & $\begin{array}{l}\text { Care. } \\
\text { Non-profit LTCF*. }\end{array}$ \\
\hline $\begin{array}{l}\text { Satisfaction of elderly } \\
\text { persons and nursing } \\
\text { professionals with care } \\
\text { provided in a LTCF. } \\
\text { Castro et al. }\end{array}$ & $\begin{array}{l}\text { Journal of } \\
\text { Research } \\
\text { Fundamental } \\
\text { Care (On-line) } \\
2013\end{array}$ & $\begin{array}{l}\text { Identify the level of satisfaction of } \\
\text { elderly persons with the quality of } \\
\text { health care provided by nursing } \\
\text { professionals and the level of } \\
\text { satisfaction of these professionals } \\
\text { with the activities they perform. } \\
23 \text { elderly persons and eight nursing } \\
\text { professionals from an LTCF/ } \\
\text { Maringá, Paraná. }\end{array}$ & $\begin{array}{l}\text { Care and management. Type } \\
\text { of LTCF not described. }\end{array}$ \\
\hline $\begin{array}{l}\text { Indicators of } \\
\text { institutionalization of } \\
\text { elderly persons: study } \\
\text { of cases and controls. } \\
\text { Del Duca et al. }{ }^{9}\end{array}$ & $\begin{array}{l}\text { Revista de Saúde } \\
\text { Pública (Public } \\
\text { Health Journal) } \\
2012\end{array}$ & $\begin{array}{l}\text { Identify the indicators and causes } \\
\text { of the institutionalization of elderly } \\
\text { persons. } \\
991 \text { elderly persons, } 393 \text { of whom } \\
\text { were institutionalized in } 24 \text { LTCFs } \\
\text { and } 598 \text { non-institutionalized elderly } \\
\text { persons / Pelotas, Rio Grande do } \\
\text { Sul. }\end{array}$ & $\begin{array}{l}\text { Care. } \\
\text { LTCFs registered with } \\
\text { Sanitary Surveillance. Type } \\
\text { not described. }\end{array}$ \\
\hline $\begin{array}{l}\text { Perception of } \\
\text { health professionals } \\
\text { regarding the care of } \\
\text { institutionalized elderly } \\
\text { people. } \\
\text { Piexak et al. }{ }^{10}\end{array}$ & $\begin{array}{l}\text { Revista Brasileira } \\
\text { de Geriatria e } \\
\text { Gerontologia } \\
\text { (Brazilian } \\
\text { Journal of } \\
\text { Geriatrics and } \\
\text { Gerontology) } \\
2012\end{array}$ & $\begin{array}{l}\text { Identify the meaning that health } \\
\text { professionals attribute to the care of } \\
\text { institutionalized elderly people. } \\
14 \text { health professionals: nurses, } \\
\text { pharmacist, physiotherapist, } \\
\text { physician, nutritionist and nursing } \\
\text { technicians of an LTCF/in the } \\
\text { central region of the state of Rio } \\
\text { Grande do Sul. }\end{array}$ & $\begin{array}{l}\text { Care. } \\
\text { Type of LTCF not described. }\end{array}$ \\
\hline $\begin{array}{l}\text { Evaluation of Long } \\
\text { Term Care Facilities } \\
\text { for elderly persons } \\
\text { in the city of Olinda, } \\
\text { Pernambuco. } \\
\text { Angelo et al. }{ }^{11}\end{array}$ & $\begin{array}{l}\text { Revista Brasileira } \\
\text { de Geriatria e } \\
\text { Gerontologia } \\
\text { (Brazilian } \\
\text { Journal of } \\
\text { Geriatrics and } \\
\text { Gerontology) } \\
2011\end{array}$ & $\begin{array}{l}\text { To analyze the organization and } \\
\text { functioning of an LTCF, through the } \\
\text { application of a specific instrument } \\
\text { of Sanitary Surveillance, prepared in } \\
\text { 2007, verifying that the institutions } \\
\text { comply with the regulations of the } \\
\text { Ministry of Health. } \\
\text { Seven private, public and charitable } \\
\text { LTCFs /Olinda, Pernambuco. }\end{array}$ & $\begin{array}{l}\text { Management. } \\
\text { Charitable, public and private } \\
\text { LTCFs. }\end{array}$ \\
\hline $\begin{array}{l}\text { Structural linkages } \\
\text { of Long Term Care } \\
\text { Facilities for the Elderly } \\
\text { with surrounding } \\
\text { societal systems. } \\
\text { Creutzberg et al. }{ }^{12}\end{array}$ & $\begin{array}{l}\text { Revista Gaúcha } \\
\text { de Enfermagem } \\
\text { (Gaúcha Nursing } \\
\text { Journal) (Online) } \\
2011\end{array}$ & $\begin{array}{l}\text { Analyze how the internal } \\
\text { organizational system of the LTCF } \\
\text { maintained structural linkages with } \\
\text { surrounding societal systems. } \\
\text { Six LTCFs from three regions } \\
\text { of Brazil (South, Southeast and } \\
\text { Northeast). }\end{array}$ & $\begin{array}{l}\text { Management. } \\
\text { LTCFs serving low income } \\
\text { elderly persons. } \\
\text { Type of LTCFs not described. }\end{array}$ \\
\hline
\end{tabular}


continued from Table 1

\begin{tabular}{|c|c|c|c|}
\hline Articles and Authors & $\begin{array}{l}\text { Publication and } \\
\text { Year }\end{array}$ & $\begin{array}{l}\text { Objective and Participants/Study } \\
\text { Sample }\end{array}$ & $\begin{array}{l}\text { Care and/or management } \\
\text { demands identified and type } \\
\text { of LTCF. }\end{array}$ \\
\hline $\begin{array}{l}\text { Structural alterations } \\
\text { in a Long Term Care } \\
\text { Facility for the Elderly } \\
\text { aimed at the prevention } \\
\text { of falls. } \\
\text { Santos et al. }{ }^{13}\end{array}$ & $\begin{array}{l}\text { Revista Rene } \\
\text { de Fortaleza } \\
\text { (Northeast } \\
\text { Network } \\
\text { Nursing Journal) } \\
2011\end{array}$ & $\begin{array}{l}\text { Propose alterations to the physical } \\
\text { structure of the LTCF, with the aim } \\
\text { of preventing falls among elderly } \\
\text { residents. } \\
\text { One LTCF / Rio Grande do Sul. }\end{array}$ & $\begin{array}{l}\text { Care and Management. } \\
\text { Charitable LTCF. }\end{array}$ \\
\hline $\begin{array}{l}\text { Research in LTCF: } \\
\text { necessary and possible } \\
\text { contributions. } \\
\text { Creutzberg and } \\
\text { Gonçalves }^{14}\end{array}$ & $\begin{array}{l}\text { Revista Brasileira } \\
\text { de Geriatria e } \\
\text { Gerontologia } \\
\text { (Brazilian } \\
\text { Journal of } \\
\text { Geriatrics and } \\
\text { Gerontology) } \\
2010\end{array}$ & $\begin{array}{l}\text { To identify the structural linkages of } \\
\text { the LTCF with the scientific system, } \\
\text { through the perception of directors } \\
\text { on research in these settings, } \\
\text { observing the communication and } \\
\text { the resonances in the institution. } \\
\text { Seven directors of three LTCFs / } \\
\text { Porto Alegre, Rio Grande do Sul. }\end{array}$ & $\begin{array}{l}\text { Management. } \\
\text { Public and private non-profit } \\
\text { LTCFs. }\end{array}$ \\
\hline $\begin{array}{l}\text { Hospitalization and } \\
\text { associated factors } \\
\text { among residents of } \\
\text { Long Term Care } \\
\text { Facilities for the } \\
\text { Elderly. } \\
\text { Del Duca et al. }{ }^{15}\end{array}$ & $\begin{array}{l}\text { Caderno de } \\
\text { Saúde Pública } \\
\text { (Public Health } \\
\text { Notebook) } \\
2010\end{array}$ & $\begin{array}{l}\text { To assess the prevalence of hospital } \\
\text { admissions in a one-year period and } \\
\text { associated factors based on a census } \\
\text { among LTCF residents. } \\
466 \text { elderly persons from } 24 \text { LTCF/ } \\
\text { Pelotas, Rio Grande do Sul. }\end{array}$ & $\begin{array}{l}\text { Care and Management. } \\
\text { LTCFs registered with } \\
\text { Sanitary Surveillance. } \\
\text { Type of LTCF not described. }\end{array}$ \\
\hline $\begin{array}{l}\text { Process of care in Long } \\
\text { Term Care Facilities: } \\
\text { view of formal } \\
\text { caregivers of elderly } \\
\text { persons. } \\
\text { Ribeiro et al. }{ }^{16}\end{array}$ & $\begin{array}{l}\text { Revista Brasileira } \\
\text { de Enfermagem } \\
\text { (Journal of } \\
\text { Brazilian } \\
\text { Nursing) } \\
2009\end{array}$ & $\begin{array}{l}\text { Evaluate the care provided in } \\
\text { charitable and private LTCFs, } \\
\text { according to the elderly person/ } \\
\text { caregiver relationship, their training, } \\
\text { satisfaction, difficulties with the role } \\
\text { and activities performed. } \\
181 \text { caregivers of elderly persons/ } \\
\text { Belo Horizonte, Minas Gerais. }\end{array}$ & $\begin{array}{l}\text { Care. } \\
\text { Charitable and private LTCFs. }\end{array}$ \\
\hline $\begin{array}{l}\text { Residences for older } \\
\text { adults: basic criteria for } \\
\text { suitable choices. } \\
\text { Vergara RS. } .^{17}\end{array}$ & $\begin{array}{l}\text { Revista do } \\
\text { Hospital das } \\
\text { Clínicas da } \\
\text { Universidade do } \\
\text { Chile (Journal of } \\
\text { Clinical Hospital } \\
\text { of University of } \\
\text { Chile) } \\
2008\end{array}$ & $\begin{array}{l}\text { Indicate basic factors to be } \\
\text { considered in the selection and } \\
\text { choice of LTCFS. } \\
\text { Carried out with official data from } \\
\text { the Ministry of Health of Chile, } \\
\text { relating to LTCFs in that country. }\end{array}$ & $\begin{array}{l}\text { Care. } \\
\text { Type of LTCF not described. }\end{array}$ \\
\hline $\begin{array}{l}\text { Long Term Care } \\
\text { Facilities for the } \\
\text { Elderly: the image that } \\
\text { remains. } \\
\text { Creutzberg et al. }{ }^{18}\end{array}$ & $\begin{array}{l}\text { Texto e Contexto } \\
\text { Enfermagem } \\
\text { (Nursing Text } \\
\text { and Context) } \\
2008\end{array}$ & $\begin{array}{l}\text { Identify the structural linkages of } \\
\text { the LTCFs with the societal system, } \\
\text { observing the communication and } \\
\text { the resonances in the institution. } \\
\text { Seven directors and } 52 \text { LTCFs } \\
\text { (South, Southeast and Northeast) }\end{array}$ & $\begin{array}{l}\text { Management. } \\
\text { Public and private LTCFs. }\end{array}$ \\
\hline
\end{tabular}


continued from Table 1

\begin{tabular}{|c|c|c|c|}
\hline Articles and Authors & $\begin{array}{l}\text { Publication and } \\
\text { Year }\end{array}$ & $\begin{array}{l}\text { Objective and Participants/Study } \\
\text { Sample }\end{array}$ & $\begin{array}{l}\text { Care and/or management } \\
\text { demands identified and type } \\
\text { of LTCF. }\end{array}$ \\
\hline $\begin{array}{l}\text { The mechanisms } \\
\text { of health in the } \\
\text { elderly: a study with } \\
\text { institutionalized elderly } \\
\text { persons. } \\
\text { Pestana and Espírito } \\
\text { Santo }^{19}\end{array}$ & $\begin{array}{l}\text { Revista da Escola } \\
\text { de Enfermagem } \\
\text { da Universidade } \\
\text { de São Paulo } \\
\text { (USP) (The } \\
\text { Journal of the } \\
\text { Nursing School } \\
\text { of the University } \\
\text { of São Paulo) } \\
2008\end{array}$ & $\begin{array}{l}\text { Describe the health situation of } \\
\text { the elderly in an institutionalized } \\
\text { context and identify how they } \\
\text { perceive their health. } \\
17 \text { elderly persons from a LTCF/Rio } \\
\text { de Janeiro. }\end{array}$ & $\begin{array}{l}\text { Care. } \\
\text { Charitable LTCF. }\end{array}$ \\
\hline $\begin{array}{l}\text { Profile of caregivers of } \\
\text { elderly persons in Long } \\
\text { Term Care Facilities in } \\
\text { Belo Horizonte, Minas } \\
\text { Gerais. } \\
\text { Ribeiro et al. }{ }^{20}\end{array}$ & $\begin{array}{l}\text { Ciência de Saúde } \\
\text { Coletiva } \\
2008 \text { (Public } \\
\text { Health Science) }\end{array}$ & $\begin{array}{l}\text { Evaluate the profile of caregivers of } \\
\text { elderly persons from charitable and } \\
\text { private LTCFs. } \\
181 \text { caregivers of elderly persons/ } \\
\text { Belo Horizonte, Minas Gerais. }\end{array}$ & $\begin{array}{l}\text { Care and Management. } \\
\text { Charitable and private LTCFs. }\end{array}$ \\
\hline $\begin{array}{l}\text { The quality of life of } \\
\text { the institutionalized } \\
\text { elderly person in } \\
\text { homes. } \\
\text { Almeida and } \\
\text { Rodrigues }^{21}\end{array}$ & $\begin{array}{l}\text { Revista Latino- } \\
\text { Americana de } \\
\text { Enfermagem } \\
\text { (Latin-American } \\
\text { Nursing Journal) } \\
2008\end{array}$ & $\begin{array}{l}\text { To describe the quality of life and } \\
\text { factors that influence it and to } \\
\text { identify the degree of dependence } \\
\text { in basic activities of daily living of } \\
\text { institutionalized elderly persons. } \\
93 \text { elderly persons from four } \\
\text { LTCFs / City of Lamego, Portugal. }\end{array}$ & $\begin{array}{l}\text { Care. } \\
\text { Type of LTCF not described. }\end{array}$ \\
\hline $\begin{array}{l}\text { The meaning attributed } \\
\text { to 'being elderly' by } \\
\text { workers from Long- } \\
\text { Term Care Facilities. } \\
\text { Reis and Ceolim². }\end{array}$ & $\begin{array}{l}\text { Revista da Escola } \\
\text { de Enfermagem } \\
\text { da Universidade } \\
\text { de São Paulo } \\
\text { (USP) (The } \\
\text { Journal of the } \\
\text { Nursing School } \\
\text { of the University } \\
\text { of São Paulo) } \\
2007\end{array}$ & $\begin{array}{l}\text { Identify the meaning attributed } \\
\text { to "being elderly" by workers who } \\
\text { provide direct nursing care to } \\
\text { institutionalized elderly persons. } \\
50 \text { professionals from five LTCFs/ } \\
\text { Campinas, Sao Paulo. }\end{array}$ & $\begin{array}{l}\text { Care. } \\
\text { LTCF registered with the city } \\
\text { council. }\end{array}$ \\
\hline $\begin{array}{l}\text { The economic survival } \\
\text { of Long Term Care } \\
\text { Facilities for Poor } \\
\text { Elderly Persons. } \\
\text { Creutzberg et al. }\end{array}$ & $\begin{array}{l}\text { Revista Latino- } \\
\text { Americana de } \\
\text { Enfermagem } \\
\text { (Latin-American } \\
\text { Nursing Journal) } \\
2007\end{array}$ & $\begin{array}{l}\text { Identify structural linkages of } \\
\text { LTCFs with the economic system, } \\
\text { to maintain institutions that provide } \\
\text { accommodation to poor Brazilian } \\
\text { elderly persons. } \\
\text { Seven directors, eight elderly } \\
\text { persons and } 52 \text { LTCFs, Brazil. }\end{array}$ & $\begin{array}{l}\text { Management. } \\
\text { Public and private non-profit } \\
\text { LTCFs. }\end{array}$ \\
\hline
\end{tabular}

Data from survey (2015); *Long Term Care Facility for Elderly Persons. 
Most articles were published in 2008, followed by 2011 with three, 2013, 2012, 2010 and 2007 with two articles each, and 2009 with one.

In the articles of this review the interest of researchers in describing the reality of the institutions from the point of view of the professionals who work in LTCFs and of the elderly individuals is evident. Of the 17 articles selected, $47.05 \%$ used the interview as a tool for data collection. A total of $50 \%$ of such interviews were with professionals of the LTCF, $25 \%$ were with managers, $12.5 \%$ were with elderly persons, and $12.5 \%$ were with both professionals working in the LTCF and elderly persons. Nine articles $(52.95 \%)$ used statistical, demographic and epidemiological data.

The last column of Table 1 shows the type of demand identified in the articles, whether care and/or management related, and the type of LTCF. Care demands predominated, with eight articles providing content associated with the care needs of the elderly, five describing content relevant to LTCF management issues, and four involving both types of demands. In terms of the type of LTCFs, private non-profit institutions appeared three times, private institutions, four times, public facilities, five times, and charitable institutions, six times. The type of LTCF was not described in seven studies.

A total of 108 institutions were included along with 1728 elderly persons, seven directors and 203 professionals (Table 1).

\section{DISCUSSION}

An opening finding regarding issues related to LTCFs is the aim of changing the negative aspects of these organizations, which are sometimes referred to pejoratively as "asylums". The transformation begins by changing the nomenclature itself, as they become LTCFs. The studies analyzed showed that efforts are being made by those involved in the care of institutionalized elderly persons to provide them with better living conditions.

There was a predominance of female residents in the LTCFs in all the studies, with the exception of one of the articles surveyed ${ }^{8}$. The explanation for the predominance of women is consensual among the authors.

The transformations that have been taking place in the population pyramid indicate greater survival rates among women than men, as they are less exposed to occupational risks and adopt fewer behaviors of risk ${ }^{9}$. Men occupy more jobs that require greater physical effort, and have a greater consumption of alcoholic beverages and tobacco, in addition to presenting higher mortality rates due to external causes, such as situations of violence, which especially affect young people 9 . In turn, women tend to take better care of themselves and to use health services more assiduously?

Therefore, the reasons that lead to greater life expectancy of the female population affect the profile of institutionalized elderly women, who have characteristics such as being widowed and having a low educational level. This variable is related to historical and cultural factors, as women have less access to formal education, and their activities are more restricted to the domestic space ${ }^{9,19}$.

The causes of institutionalization can be hierarchized at four levels (Figure 1). 


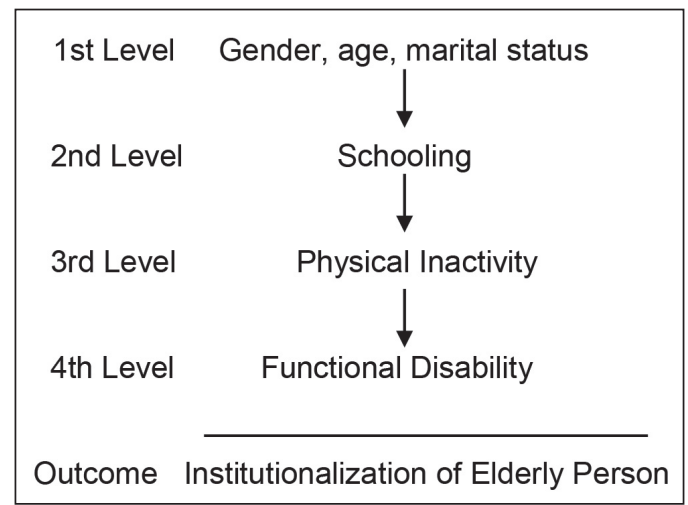

Figure 1. Causes of institutionalization by hierarchical level, Pelotas, Rio Grande do Sul, 2008.

Adapted from Del Duca et al. ${ }^{9}$.

The family has a fundamental role in the process of institutionalization. In the family dynamic, the loss of a spouse is a determining factor for the surviving elderly person to move to an LTCF, as the mere existence of the family does not guarantee the permanence of such individuals in the family nucleus. The imminence of widowhood has psychological and economic repercussions for the life of the elderly, influencing when one opts for institutionalization ${ }^{19}$.

The study by Angelo et al..$^{11}$ states that:

Institutionalization can bring countless consequences, since any change, however simple, implies both positive and negative factors. The main change is adaptation to institutionalized life, because however comfortable an elderly person is with the idea of living in an institution, they have their hobbies, habits, tasks, and their role as a grandfather/grandmother, father or mother. The family is considered the natural habitat for human beings. In it we are more natural, more ourselves, more understood for our defects and our qualities, without social masks.

Another study points out that adaptation is more difficult for men, who are more critical of life in the "asylum"19. They adopt a posture that suggests they will never adapt or as though they are there unwillingly, due to a lack of options. Women provide a more accepting discourse, although they criticize some of the practices of the institution.
Only one study ${ }^{21}$ describes the number of cases of institutionalization that occur due to the decision of the family or based on the initiative of the elderly persons themselves. Of the 93 elderly individuals in the study, $46.2 \%$ reported having moved to the LTCF of their own account, $30.1 \%$ due to a decision by their children and the remainder $(23.7 \%)$ for other reasons related to the family context. The authors also argue that elderly persons should remain in the family unit $^{21}$. In addition, the type of LTCF reflects the social and economic characteristics of the residents and, therefore, the reason for institutionalization.

Considering that the choice of an LTCF should be made by the family, with the participation of the elderly person as this decision will affect them directly, some criteria of this process can be considered, such as: verifying the proximity of the institution to the homes of relatives; the availability of vacancies; scheduling visits, checking the records and business license of the facility and evaluating the physical structure and the professional team; requesting a conversation with the director of the LTCF and addressing issues such as emergency medical care, the routine of the institution and whether the objects used by the elderly person will be personal or shared. After selecting the LTCF, the elderly person should be visited frequently, without prior notice, evaluating their physical and mental state, in addition to observing compliance with what was agreed at the time the individual entered the facility ${ }^{17}$. 
Particular care should be given to the degree of dependency of the elderly persons and issues that reflect their quality of life. In addition to being one of the causes for hospitalization, this interrelationship is a determinant for the type of care they require and serves as the basis for defining the infrastructure and organization of the LTCF.

Therefore, the focus of the institutional organization is to prioritize the quality of life of elderly people. Quality of life is defined by the World Health Organization (WHO) ${ }^{24}$ as the "individual's perception of their position in life in the context of the culture and value systems in which they live and in relation to their goals, expectations, standards and concerns". It should be noted that in the aging process quality of life is linked to the satisfaction an individual feels in the environment in which they live. In this way, elderly persons seek comfort and well-being in the amorous and social relationships that they establish, and their quality of life is strongly associated with their capacity to maintain autonomy, perform tasks and make decisions ${ }^{25}$.

In the view of elderly persons, health is not related to the absence of diseases and pathologies, but to not feeling the symptoms provoked by these conditions and/or, as is the case with the majority of people, for example, some type of chronic disease, hypertension or diabetes ${ }^{19}$. Negative feelings such as loneliness, abandonment, dependence, and unproductiveness trigger a state of illness, from which the sensations of bodily pain arise ${ }^{19}$. One study pointed out that $60 \%$ of elderly persons presented degrees of dependence for Activities of Daily Living (ADL), with the most impaired activities being dressing, bathing and personal hygiene?

Among the professionals who provide care for elderly people in LTCFs, the most important are the caregivers and nursing professionals, most notably the nursing assistants. Of the 50 professionals interviewed in a survey, $94 \%$ were women, $36 \%$ were aged from 31 to 40 years old; $42 \%$ did not complete elementary education and $90 \%$ were not trained to care for the elderly, having acquired experience for such work through life and/or care of relatives.

A survey ${ }^{20}$ with 181 caregivers showed that $87.8 \%$ were women, $87.3 \%$ were less than 50 years old, and $42 \%$ had less than four years of schooling. In the discourses of the interviewees, the researchers identified a subtle association with a depreciative image of older people, who were seen as fragile, rejected by society and infantilized, which contributed to a reduced incentive to respect their autonomy and independence. "The lack of training of these professionals often leads to erroneous practices linked to stereotypes associated with aging"20. In another study ${ }^{16}$ with similar results, the authors reported that, despite the lack of training, the caregivers revealed that they felt satisfied with their work ${ }^{16}$.

In the context of LTCFs, the formation of a multidisciplinary team is considered essential and can stimulate interdisciplinary action, which is the possibility of transforming the reality in which one acts through the union of theoretical knowledge and practice with a common objective ${ }^{10}$. In the same study, LTCF professionals reported being aware of the importance of this type of action, but declared they were unable to adopt it for various reasons, among them problems with the management of the $\mathrm{LTCF}^{10}$.

Remaining with the subject of multidisciplinary teams, another survey ${ }^{11}$ identified that $100 \%$ of such groups featured an administrator, $57.1 \%$ included medical and social care services, $85.7 \%$ had a nutritional service, $71.4 \%$ had nursing technicians and $42.8 \%$ had a secretary, psychologist and nurse ${ }^{11}$.

In general, the LTCFs managed to maintain only basic teams, disregarding the importance of having the support of multi-professional teams, composed of physiotherapists, speech therapists, physical educators and dentists, despite the fact the group action of these professionals provides integral care for the elderly, helping to prevent diseases, the promotion and recovery of health and the maintenance of life. ${ }^{22,24}$.

There is a passing mention of dental services in the study by Vergara ${ }^{17}$. Although there are no direct citations of physical trainers, the performance of complementary physical and other activities, such as recreation, leisure, culture and religion is described in all the works analyzed. These are considered vital for the well-being of the elderly and an incentive to their greater independence and autonomy, although are only opportune when structural conditions allow. The presence of volunteer professionals is an alternative for these activities that has been identified by LTCFs, although there is no standardization of 
the services offered by such individuals and/or their provision in a systematic manner ${ }^{10}$.

Nutrition services are provided by some of the $\mathrm{LTCFs}^{10,11}$, where six meals are served daily with the aim of adapting the menu to the diet of elderly persons, but without their participation in the choice. It was found by researchers that these LTCFs lacked effective hygiene and food preparation and storage practices, increasing the chances of contamination or food poisoning ${ }^{10,11}$.

Some studies ${ }^{12,15}$ elucidate important points related to limited financial resources: a staffing shortfall and insufficiently trained professionals, an unsuitable physical structure and a deficit of self-help equipment, increasing the risk of falls, the cost of residing in the facility and/or leading elderly persons to hospitalization.

When institutionalized elderly persons are compared with those who are resident in the community from the same age range, a greater rate of hospitalization is found among the former ${ }^{15}$. In the 24 LTCFs studied, elderly persons with functional and/or cognitive incapacity for the performance of ADL were 2.5 times more likely to be hospitalized than those who were able to perform such activities. Among those who suffered falls, the rate of hospitalization was $80 \%$ greater for elderly persons who resided in $\mathrm{LTCFs}^{15}$.
Regarding the integration of LTCFs with the health care network, one study ${ }^{12}$ showed that of six LTCFs studied, two did not have any link with the basic public health service; two established a link only during vaccination campaigns; five had agreements with private health services, but also used the access to hospitalization of the Sistema Único de Saúde (the Unified Health System) (SUS); one had a partner hospital, and some elderly persons used health insurance. Four reported that the care of the elderly persons in the final stage of life were provided internally, even without a suitable infrastructure; in one physical restructuring was carried out to provide palliative care. In all LTCFs, access to medication was partially guaranteed.

Another study ${ }^{13}$ showed that none of the professionals that worked in the LTCF were aware of ANVISA RDC n. 283, the directive that regulates LTCFs in Brazil, while administrators denied there were failings in compliance with legislation. In this study, researchers cited Decision n. 006/2009 of the Conselho Regional de Enfermagem do Rio Grande do Sul (the Regional Nursing Council of Rio Grande do Sul) (CRE/RS), which states that it is the responsibility of the nurse to request from the institution the physical infrastructure that meets the needs of the elderly residents. The authors of the same study proposed actions aimed at the prevention of falls in light of RDC n. 283 (Table 2).

Table 2. Proposed actions aimed at the prevention of falls among institutionalized elderly persons. Rio Grande do Sul, 2010.

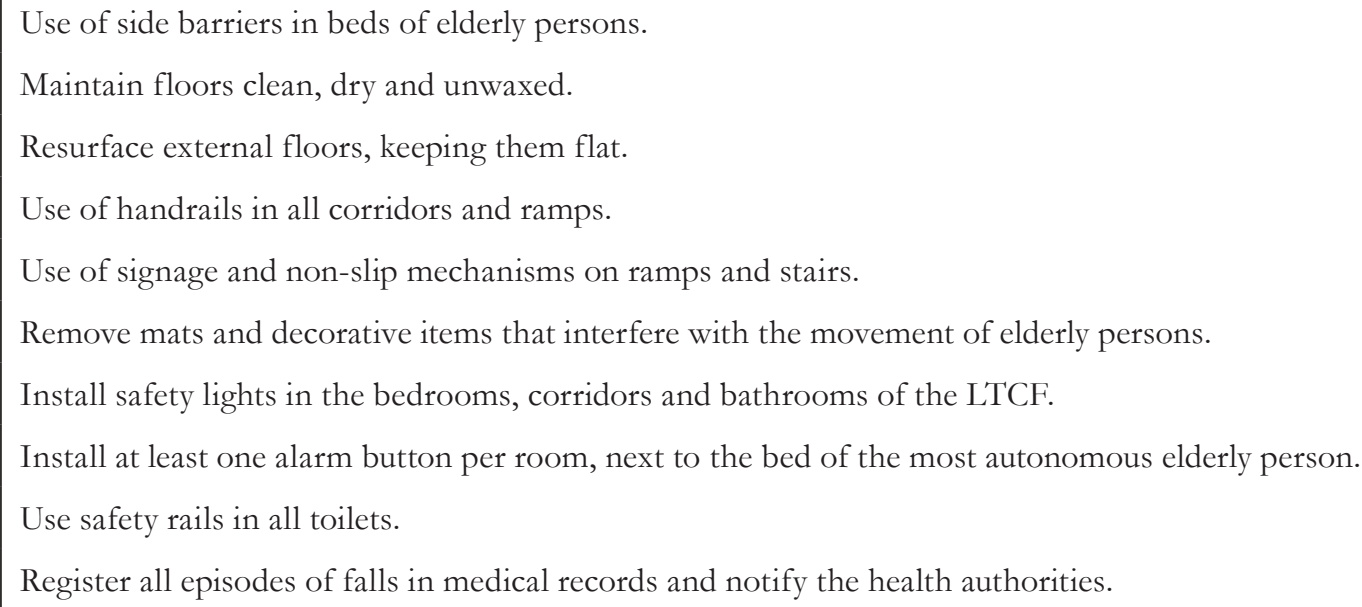


It is important to stress that LTCFs are organizations that are established in a social context as part of the public health care network for the elderly ${ }^{12}$. They have undergone a process of transformation from asylum type care, becoming institutions that provide integral and quality care, in order to meet the expectations of elderly persons and society ${ }^{12}$.

To fulfill their role with quality and effectiveness, LTCFs must professionalize their management structure, despite often lacking resources to do so. One study ${ }^{23}$ escribed that the monthly cost per elderly person was, on average, $\mathrm{R} \$ 500,00$ in 2007 , representing $131.6 \%$ of the minimum salary at the time (MS), which was $\mathrm{R} \$ 380.00^{27}$. Updating these values with the Citizen's Calculator ${ }^{26}$, which adopts the General Market Price Index (IGP-M) of the Getúlio Vargas Foundation (FGV), in November 2015, the monthly cost of an elderly person in an LTCF was $\mathrm{R} \$ 839.00$, which corresponds to $95.3 \%$ of the MS $(\mathrm{R} \$ 880.00)$ in that year. This result, however, does not explain whether the reduction of costs resulted in an improvement in the quality and effectiveness of services. Using the same index, the cost of purchasing medication would be approximately $\mathrm{R} \$ 20,000.00$ per month per LTCF in November 2015, revealing the high cost of medications in this phase of life.

To meet expenses, LTCFs rely on various sources of income $e^{27,28}$. The pension of the elderly persons is the most significant, with institutions absorbing part or all of such income. The Statute of the Elderly allows that part of the income of the elderly can be assumed by the LTCFs, provided that the elderly person retains a percentage and the value absorbed by the LTCF does not exceed $70 \%$ of the income. The majority of elderly persons, however, stated that they were denied this right ${ }^{23}$. Other income sources of LTCFs are public funds, which are usually received late and in smaller values than requested, as well as partnerships with private initiatives, donations and volunteering $^{23}$.

In general, charitable and public LTCFs rely heavily on fairs, bazaars, raffles, public holiday celebrations and events and projects with other LTCFs $^{18,19,23}$. The type of administration is a sine qua non factor for the undertaking of these activities. LTCFs also represent a means for elderly persons to socialize. It should be noted that the significant number of scientific investigations in LTCFs often causes discomfort, undue exposure and the invasion of the privacy of elderly persons, with the return to institutions limited or even non-existent ${ }^{14,18}$.

Figure 2 summarizes the care and management demands of the LTCFs identified in this review. The external part of the circle includes a synthesis of the studies on which this work is based, allowing comparison between the real and the desirable.

The exclusion of articles with access linked to payment was a limitation of the present study, summarized in Figure 2, as PubMed's Englishlanguage publications were not included. Such exclusion may have restricted a more comprehensive review of LTCF management and care demands from 2004 to 2014. 


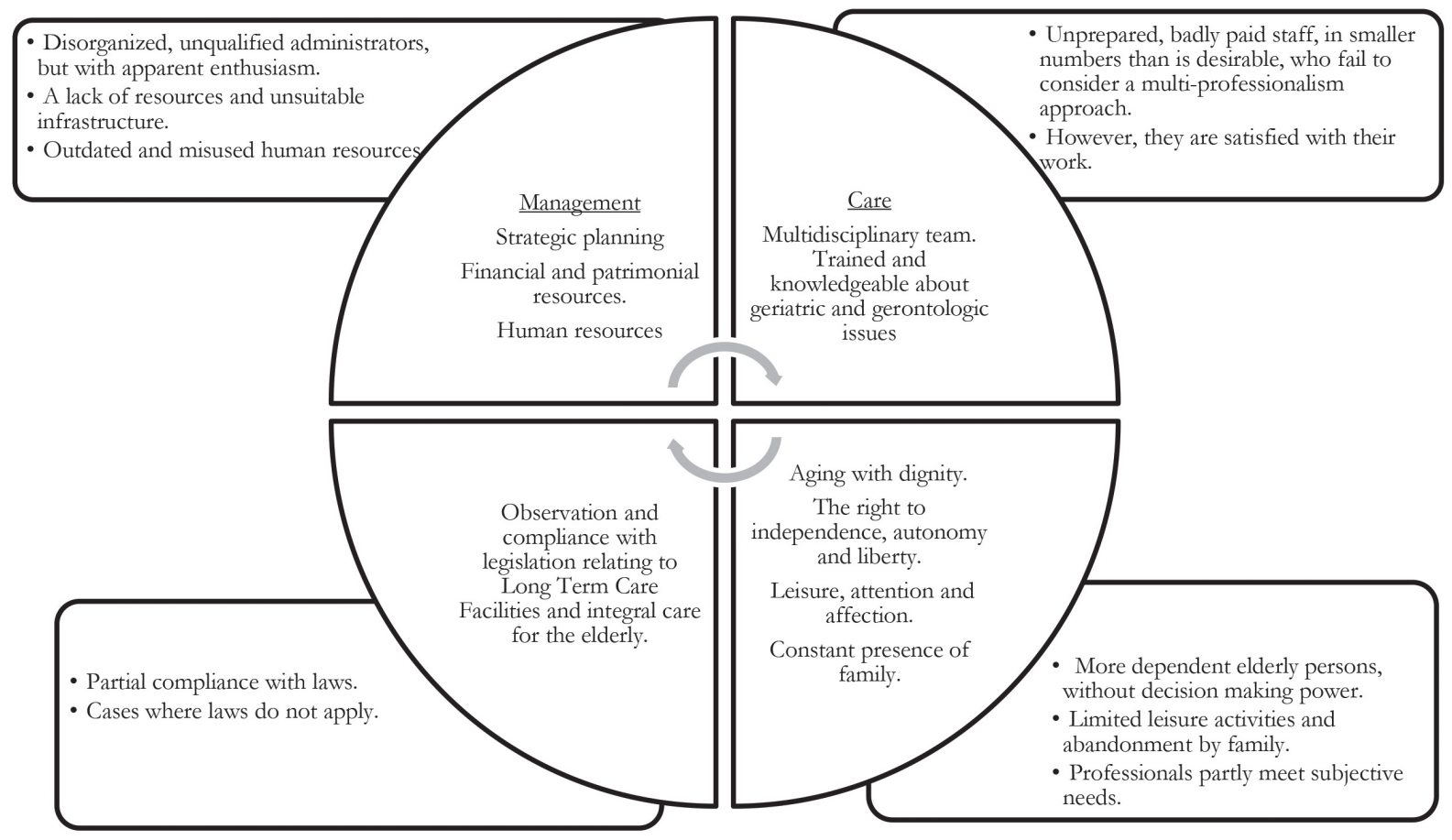

Figure 2. Management and care demands of Long Term Care Facilities for Elderly Persons identified in this integrative review. Belo Horizonte, Minas Gerais, 2015

\section{CONCLUSION}

In response to the objectives of this study, it can be concluded that the care demands identified in Brazil from 2004 to 2014 are related to the provision of care and the need for teams with geriatric and gerontological knowledge, capable of offering comprehensive care, while the management demands are related to the resources required for the effective provision of care.

Most of the studies concentrated on the medical and clinical aspects of the elderly persons residing in LTCFs. The publications that made up the sample of this study often discussed care demands. There was a shortage of studies that addressed the management demands of the LTCFs in a specific and detailed manner, which could have provided an insight into the organizational practices adopted by these institutions, as well as advances and challenges in the management of these organizations.
The majority of the LTCFs featured in the researched articles were of charitable origin, with the others described as being either private and private nonprofit in origin. There was also a study of a public LTCF and those registered with public organs. Seven articles did not describe the type of LTCF. In general, the care and management demands identified did not differ significantly based on the nature of the LTCF, a finding which should be investigated in future studies.

The staff of the majority of the LTCFs studied were unprepared for the performance of their roles, both in terms of providing care to the elderly and for managing the institution, meaning that the services offered are restricted to the essentials needed to guarantee the survival of the elderly residents.

It is hoped that the results of this study will alert scholars to the need for investment in descriptive research in LTCFs in Brazil and another countries, 
so that the theoretical knowledge acquired can foster positive actions in the practices of these organizations. The professionalization of management in LTCFs is an urgent need if the elderly persons who reside in them are to be provided with effective, quality care that meets their needs in this phase of life.

In view of the implications of the phenomenon of population aging in Brazil, the need for LTCFs in the near future is evident. While they will not replace the value and importance of elderly persons living with their family, they can represent an extension of the family unit if there is positive synergy, love and commitment among those involved, as well as sufficient investment to allow the provision of a dignified life for the elderly population of Brazil and another countries.

\section{ACKNOWLEDGEMENTS}

The authors would like to thank the State of Minas Gerais Research Support Foundation (FAPEMIG) for financial support.

\section{REFERENCES}

1. Camarano AA, Kanso S. As instituições de longa permanência para idosos no Brasil. Rev Bras Estud Popul. 2010;27(1):232-5.

2. Pollo SHL, Assis M. Instituições de longa permanência para idosos - ILPIS: desafios e alternativas no município do Rio de Janeiro. Rev Bras Geriatr Gerontol [Internet]. 2008 [acesso em 01 ago. 2014];11(1):29-44. Disponível em: http://www.redalyc. org/pdf/4038/403838777004.pdf

3. Oliveira JM, Rozendo CA. Instituição de longa permanência para idosos: um lugar de cuidado para quem não tem opção? Rev Bras Enferm. 2014;67(5):773-9.

4. BRASIL. Agência Nacional de Vigilância Sanitária. Resolução RDC n ${ }^{\circ}$ 283, de 26 de setembro de 2005. Aprova Regulamento Técnico para o Funcionamento das Instituições de Longa Permanência para Idosos. Diário Oficial da União, 27 set. 2005.

5. Michaellis: dicionário de português online [Internet]. São Paulo: Melhoramentos; 2014 [acesso em 28 jul. 2014]. Disponível em: http://michaelis.uol.com.br/ moderno/portugues/index.php?lingua=portuguesportugues\&palavra $=$ assistencia

6. Souza MT, Silva MD, Carvalho R. Revisão integrativa: o que é e como fazer. Einstein. 2010;8(1):102-6.

7. Marinho LM, Vieira MA, Costa SM, Andrade JMO. Grau de dependência de idosos residentes em instituições de longa permanência. Rev Gaúch Enferm. 2013;34(1):104-10.
8. Castro VC, Derhun FM, Carreira L. Satisfação de idosos e profissionais de enfermagem com o cuidado prestado em uma instituição asilar. J Res Fundam Care [Internet]. 2013 [acesso em 28 jul. 2014];5(4):493502. Disponível em: http://www.seer.unirio.br/index. php/cuidadofundamental/article/view/2282/pdf_912

9. Del Duca GF, Silva SG, Thumé E, Santos IS, Hallal PC. Indicadores de institucionalização de idosos: estudo de casos e controles. Rev Saúde Pública. 2012;46(1):147-53.

10. Piexak DR, Freitas PH, Backes DS, Moreschi C, Ferreira CLL, Souza MHT. Percepção de profissionais de saúde em relação ao cuidado a pessoas idosas institucionalizadas. Rev Bras Geriatr Gerontol. 2012;15(2):201-8.

11. Angelo BHB, Silva DIB, Lima MAS. Avaliação das instituições de longa permanência para idosos do município de Olinda-PE. Rev Bras Geriatr Gerontol. 2011;14(4):663-73.

12. Creutzberg M, Gonçalves LHT, Santos BL, Santos SSC, Pelzer MT, Portella MR, et al. Acoplamento estrutural das instituições de longa permanência para idosos com sistemas societais do entorno. Rev Gaúch Enferm. 2011;32(2):19-25.

13. Santos SCS, Vidal DAS, Gautério DP, Silva ME, Rosales RA, Pelzer MT. Alterações estruturais numa ILPIs visando prevenção de quedas. Rev Rene. 2011;12(4):790-7. 
14. Creutzberg M, Gonçalves LHT. Pesquisa em instituições de longa permanência para idosos: contribuições necessárias e possíveis. Rev Bras Geriatr Gerontol. 2010;13(3):361-7.

15. Del Duca GF, Nader GA, Santos IS, Hallal PC. Hospitalização e fatores associados entre residentes de instituições de longa permanência para idosos. Cad Saúde Pública. 2010;26(7):1403-10.

16. Ribeiro MTF, Ferreira RC, Magalhães CS, Moreira AN, Ferreira EF. Processo de cuidar nas instituições de longa permanência: visão dos cuidadores formais de idosos. Rev Bras Enferm. 2009;62(6):870-5.

17. Vergara RS. Residencias para adultos mayores: criterios básicos para su adecuada selección. Rev Hosp Clín Univ Chile. 2008;19:356-60.

18. Creutzberg M, Gonçalves LHT, Sobottka EA. Instituição de longa permanência para Idosos: a imagem que permanece. Texto \& Contexto Enferm. 2008;17(2):273-9.

19. Pestana LC, Santo FHE. As engrenagens da saúde na terceira idade: um estudo com idosos asilados. Rev Esc Enferm USP. 2008;42(2):268-75.

20. Ribeiro MTF, Ferreira RC, Ferreira EF, Magalhães CS, Moreira AN. Perfil dos cuidadores de idosos nas instituições de longa permanência de Belo Horizonte, MG. Ciênc Saúde Coletiva. 2008;13(4):1285-92.

21. Almeida AJPS, Rodrigues VMCP. A qualidade de vida da pessoa idosa institucionalizada em lares. Rev Latinoam Enferm. 2008;16(6):1025-31.
22. Reis PO, Ceolim MF. O significado atribuído a 'ser idoso' por trabalhadores de instituições de longa permanência. Rev Esc Enferm USP. 2007;41(1):57-64.

23. Creutzberg M, Gonçalves LHT, Sobottka EA. A sobrevivência econômica de instituições de longa permanência para idosos empobrecidos. Rev Latinoam Enferm. 2007;15(n. esp.):147-54.

24. WHOQOL Group. The World Health Organization quality of life assessment (WHOQOL): position paper from the World Health Organization. Soc Sci Med. 1995;41(10):1403-9.

25. Arantes RC. Diretrizes para a gestão do envelhecimento ativo e com qualidade de vida para idosos brasileiros. In: Lina F, Calábria L, Alves W, organizadoras. Envelhecimento: um olhar interdisciplinar. São Paulo: Hucitec; 2016. p.188-214.

26. Banco Central do Brasil [Internet]. Calculadora do cidadão: correção de valores. Brasília, DF: BC; 2015. [acesso em 09 dez 2015]. Disponível em: https://www3.bcb.gov.br/CALCIDADAO/publico/ exibirFormCorrecaoValores.do?method=exibirForm CorrecaoValores

27. BRASIL. Lei no 10741 de 01 de outubro de 2003. Dispõe sobre o Estatuto do Idoso e dá outras providências. Diário Oficial da União, 03 out. 2003.

28. Brasil, Lei no 1074/2003. Estatuto do Idoso. Brasília: Distrito Federal, Outubro de 2003. 